http://ejournal.uhn.ac.id/index.php/opinion

\title{
PROBLEMATIKA IMPLEMENTASI PERATURAN DAERAH KABUPATEN KARO NOMOR 3 TAHUN 2012 TENTANG PAJAK DAERAH
}

\author{
Michail Wiliem's Siberonta' dan Manoras Taraja ${ }^{2}$ \\ Program Studi Magister Hukum \\ Program Pascasarjana \\ Universitas HKBP Nommensen, Medan-Sumatera Utara-Indonesia \\ e-mail: michailsiberonta@yahoo.com
}

\begin{abstract}
Tax area is one of the important sources of local revenue to finance the development of a lauarge, real and responsible of aoutonoumos area, The role of the constructor visible in every project that undertaken by the government ic alwaayson the buzz of the project being build finance from the funds that have been mede lip of the society. Tax economic perspective as a mive from the private sector to the public sector. This understanding iustrates the exsistence of two situation being changed, first the ddiminished a bilitiy of individuals in control this understanding iustrates the sexsistence of two situation being changed. First the diminished abiling of individuals in control of resources for the importance of control goods and services. Increased local financial capasitiy in the provision of public goods and serulces the necessities of people's live white the development from a legal perspektife is a bond that arises because of the regulations to the emergence of the comonity to defate certain income to the emergence of the comunitiy to defecate certain income to the region. The area that have the advantage to assert the impose and money of the area must be used to implement of the area, ftom this legal appreaceh to consider the law must be based on a regulation that ensures a legal. Certainty, both, both taxis as tax convectors and tax payers as payers tax payable. From various definitions give to the tax elther divectly or juridi cally drawn conclusion about the characteristics the exsistence of tunds transfer (resources) of the private sector (tax payers paying taxes) to the regional/state sector (tax administratios).
\end{abstract}

Keywords : tax, regional income, regional autonomy

\begin{abstract}
Abstrak
Pajak Daerah merupakan salah satu sumber pendapatan asli daerah yang penting guna membiayai penyelenggaraan pemerintah daerah untuk memantafkan otonomi daerah yang luas, nyata dan bertanggung jawab. Peran pajak dalam pembangunan yang terlihat dalam setiap proyek yang dilaksanakan pemerintah selalu didengungkan bahwa proyek yang dibangun dibiayai dari dana pajak yang dikumpulkan dari masyarakat. Pajak perspektif ekonomi dipahami sebagai beralihnya sumberdaya dari sector swasta kepada sector publik. Pemahaman ini memberikan gambaran bahwa adanya pajak menyebabkan dua situasi menjadi berubah. Pertama, berkurangnya kemampuan individu dalam menguasai sumberdaya untuk kepentingan penguasaan barang dan jasa. Bertambahnya kemampuan keuangan daerah dalam penyediaan barang dan jasa public yang merupakan kebutuhan hidup masyarakat. Sementara pembangunan pajak dari persepektif hukum merupakan suatu perikatan yang timbul karna adanya suatu peraturan yang menyebabkan suatu pertikaian yang timbul karna adanya peraturan daerah mengakibatkan timbulnya kewajiban masyarakat untuk menyetor sejumlah pengahasilan tertentu kepada daerah. Daerah mempunyai keuntungan untuk memaksakan dan uang daerah tersebut harus dipergunakan untuk menyelengarakan pemerintahan dan
\end{abstract}


pembangunan daerah tersebut, dari pendekatan hukum ini memperhatikan bahwa pajak yang dipungut harus berdasarkan suatu peraturan sehingga menjamin adanya suatu kepastian hukum, baik fiskas sebagai pemungut pajak maupun wajib pajak sebagai pembayar pajak yang terhutang. Dari berbagai depenisi yang diberikan terhadap pajak baik pengertian secara ekonomis ataupun secara yuridis ditarik kesimpulan tentang cirri-ciri yang terdapat pada pengertian pajak yaitu, pajak daerah dipungut oleh Negara baik oleh pemerintah daerah berdasarkan peraturan daerah serta aturan pelaksanaanya dan pemungutan pajak mengisyaratkan adanya alih dana (sumberdaya) dari sektorswasta (wajib pajak yang membayar pajak) kesektor Daerah/Negera (pemungut pajak/administrator pajak).

Kata Kunci : pajak, pendapatan daerah, otonomi daerah

\section{A. Pendahuluan}

Pembangunan di suatu daerah dimaksudkan untuk membangun masyarakat yang seutuhnya, itu diharapkan pembangunan tersebut tidak hanya mengejar kemajuan saja, akan tetapi mencakup seluruh aspek kehidupan masyarakat yang dapat berjalan serasi dan seimbang disegala bidang dalam rangka menciptakan masyarakat adil dan makmur, kewajiban dari suatu Negara adalah melayani kebutuhan dari masyarakatnya. Dalam berbagai penyelenggaraan tugas tersebut sudah tentu diperlukan biaya, karna Negara tidak mungkin bisa melaksanakan tugas-tugas tersebut dengan sempurna, pada zaman modern sekarang biaya yang dimaksud identik dengan uang, walaupun terdapat kekecualian dalam hal pembiayaan dibantu secara materil oleh pihak pihak tertentu, untuk mendapatkan uang, atau meminjam dari luar negeri banyak jalan yang ditempu oleh pemerintah.

Pembangunan nasional dan pembangunan daerah sesungguhnya menjadi tanggung jawab Negara dan masyarakatnya. Kaitannya dengan pembangunan daerah dalam rangka otonomi daerah, pendapatan daerah menjadi sangat penting karna dapat meningkatkan taraf hidup dan kesejahteraan masyarakat. dengan pembangunan daerah yang serasi dan terpadu disertai pembangunan perencanaan yang baik efisien dan efektif maka akan tercipta kemandirian daerah dan kemajuan yang merata di seluruh Wilayah Indonesia. Beberapa Undang-undang tersebut pada dasarnya merupakan respon atas dasar aspirasi daerah di Indonesia, yang sebenarnya telah cukup lama menginginkan peningkatan peran dan kemandirian dalam mengelola tugas dan tanggung jawab serta kewenangan dalam melayani masyarakat serta meningkatkan pembangunan daerah yang kemudian bertujuan untuk mensejahterahkan masyarakatnya, hal ini mengandung makna bahwa dalam rangka Negara kesatua Republik Indonesia, kepala daerah diberikan kewenangan keleluasaan untuk menyelenggarakan kewenangan secara nyata ada dan diperlukan serta tumbuh hidup dan berkembang didaerah, termasuk segala konsekuensi kewajiban-kewajiban yang ada didalamnya, dengan tujuan akhir peningkatan pelayanan dan kesejahteraan masyarakatnya, pengembangan kehidupan berdemokrasi, keadialan, pemerataan dan pemeliharaan hubungan yang serasi antara pemerintah pusat dengan daerah. Menurut Janpatar Simamora, konsepkonsep reformasi yang lebih mumpuni dan diyakini mampu membangun kultur baru bagi birokrasi di era reformasi harus digali secara berkesinambungan demi menuju masa depan bangsa yang lebih baik serta dalam upaya menapaki langkah menuju negara maju.

Upaya pemerintah untuk membangun harus di tingkatkan dengan melakukan pembinaan dan pengarahan kepada segenap masyarakat sehingga dapat tercapai tujuan dari pembangunan itu sendiri, disamping peran serta masyarakat untuk mendukung proses kelancaran pembangunan. Untuk melaksanakan proses pembangunan yang diharapkan berkesinambungan maka suatu daerah Kabupaten/Kota di tuntut untuk lebih menggali 
seoptimal mungkin sumber daya alamnya. Seperti: Pajak, retribusi atau pungutan yang merupakan sumber-sumber pendapatan asli daerah. Adapun sumber pendapatan asli daerah yang telah di limpahkan kepada daerah oleh Negara melalui Undang-undang Nomor 28 Tahun 2009 adalah :

Jenis Pajak provinsi terdiri atas :

1. Pajak kendaraan bermotor

2. Bea Balik Nama Kendaraan Bermotor

3. Pajak Bahan Bakar Kenderaan Bermotor

4. Pajak Air Permukaan

5. Pajak Rokok

Jenis Pajak Kabupaten/Kota terdiri atas :

1. Pajak Hotel

2. Pajak Restoran

3. Pajak Hiburan

4. Pajak Reklame

5. Pajak Penerangan Jalan

6. Pajak mineral bukan Logam dan batuan

7. Pajak Parkir

8. Pajak Air Tanah

9. Pajak Sarang Burung Walet

10. Pajak Bumi dan Bangunan Perdesaan dan Perkotaan

11. Bea Perolehan Hak atas Tanah dan Bangunan

Setelah pemerintah pusat melimpahkan beberapa sumber pendapatan yang tertera di dalam Undang-undang Nomor 28 Tahun 2009 tentang pajak dan retribusi daerah kepada daerah , maka tindaklanjut oleh pemerintah daerah yaitu memuat kewenangan tersebut kedalam peratura daerah, agar daerah mempunyai paying Hukum dalam pengutipan pajak terhadap objek pajak, peraturan daerah di bentuk oleh Dewan Perwakilan Daerah dengan kepala daerah, Gubernur, Bupati, atau Walikota harus mempunyai kualitas yang baik agar peraturan daerha tersebut bisa diterapkan dengan baik dan diterima masyarakat luas terkhusus kepada masyarakat yang mempunyai pendapatan dengan cara memanfaatkan potensi dari pada daerah yang bersangkutan agar turut serta memberikan pajak untuk kemajuan pembangunan daerah tersebut.

Untuk menerapkan suatu aturan tidak cukup hanay dengan peraturan yang baik ( pro masyarakat) dan dilaksanakan oleh aparatur pemerintah yang baik ( bukan hanya sebagai corong undang-undang), akan tetapi mesti juga dilengkapi dengan budaya hokum masyarakat yang mematuhi aturan tersebut. Budaya hukum suatu masyarakat ditemukan dalam nilai-nilai tertentu yang hidup dalam masyarakat dan dijadikan acuan dalam membuat suatu aturan . Artinya, ketika suatu undang-undang dibuat harus terlebih dahulu melihat budaya hukum masyarakat yang akan diaturnya.

Suatu aturan yang tidak sesuai dengan budaya hukum masyarkat maka akan menjadi siasia belaka, aturan tersebut ibarat macan ompong yang tidak mempunyai wibawa hukum. Untuk itu, dalam pembuatan suatu aturan harus mengkaji dan mengetahui terlebih dahulu budaya hukum masyarakat yang akan diaturnya. Dalam upaya mengetahui budaya hukum tersebut, salah satu caranya adalah dengan melakukan studi ilmiah terhadap suatu peraturan yang akan dibuat yaitu biasanya dikenal dengan Naskah Akademi (NA) suatu rancangan peraturan perundang-undangan. Dalam suatu NA terdapat kajian ilmiah mengenai keadaan sosiologis masyarakat terhadap suatu aturan yang akan dibuat. Oleh sebab itu, keberadaan NA tersebut harus ada dalam setiap rancangan peraturan perundang-undangan. 
Menurut Aan Seidaman yang dikutip dari buku "Konstitusi dan Hukum dalam Kontroversi Isu" yang ditulis oleh Prof. Mahfud MD, mengatakan bahwa dalam suatu NA terdapat 7 (tujuh) indikator dan/atau faktor yang harus ada, yang dikenal dengan istilah ROCCIPI (Rules, Opportunity, Capacity, Communication, Interest, Procces dan Ideology). Dari tujuh indicator tersebut dibagi menjadi indicator subjektif dan indicator objektif. Termasuk dalam indicator dan/atau factor subjektif ini adalah interest dan Ideology.

1. Interest terkait dengan pandangan tentang manfaat bagi pelaku peran ( pembuat Undangundang maupun yang terkena atau masyarakat yang diaturnya).

2. Ideology terkait dengan masalah yang lebih luas secakupannya yakni nilai,sikap,selera, bahkan mitos-mitos dan asumsi-asumsi tentang dunia, agama, kepercayaan, politik, social, ekonomi.

Sedangkan yang termasuk indikator dan/atau factor objektif adalah Rules, Opportunity, Capacity, Communication dan Procces.

1. Rules adalah factor bahwa orang berperilaku tidak hanya dalam satu peraturan, tetapi dalam kerangka peraturan perundang-undangan yang sering saling terkait. Oleh sebab itu, pembuatannya harus selalu mengingat peraturan perundang-undangan lain yang mungkin ada kaitannya baik secara vertical maupun horizontal. Kalau ini diabaikan maka bisa timbul penolakan bahkan digugat secara hukum untuk dibatalkan melalui yudicial review.

2. Opportunity adalah factor lingkungan (eksternal) dari pihak-pihak yang akan dituju yang juga harus diketahui secara jelas sehingga memungkinkan mereka berprilaku sesuai dengan perintah atau larangan peraturan perundang-undangan yang akan dibuat. Faktor ini menuntut pembuat peraturan perundang-undangan memahmai tentang konfigurasi riil masyarakat yang akan dikenakan peraturan yang akan dibuat sebab hukum yang tidak berpijak pada realitas social tak akan dapat bekerja secara efektif.

3. Capacity adalah factor yang terkait dengan cirri-ciri pelaku (internal) yang mungkin punya masalah yang bisa mendorong mereka atau menyulit mereka atau tidak memungkinkan mereka untuk menaati peraturan perundang-undangan.

4. Communitation adalah faktor peran pihak yang berwenang atau aparat dalam mengambil langkah-langkah, apakah sudah memadai atau belum, untuk megomunikasikan peraturan perundang-undangan kepada pihak yang dituju. Pihak yang dituju untuk berlakunya peraturan perundang-undangan itu, harus mendapat informasi tentang mereka, tetapi juga mereka harus mendapat informasi dari kita tentang peraturan perundang-undangan yang akan dibuat. Oleh sebab itu, komunikai dan publikasi melalui media massa menjadi sangat penting.

5. Procces adalah prosedur bagi pelaku peran untuk memutuskan apakah akan memenuhi (mematuhi) atau tidak akan mematuhi terhadap peraturan perundang-undangan. Dari faktor ini terkandung juga keharusan agar pembentukan peraturan perundang-undangan harus melalui prosedur dan mekanisme yang berlaku untuk itu yang jika tidak diperhatikan produknya dapat terkena pengujian yudisial ( yudicial review) secara formal.

Setidaknya, dengan adanya tujuh indicator dan/atau faktor tersebut tardapat dalam NA rancangan peraturan perundang-undangan , maka masyarakat akan dapat melaksanakannya dengan suka rela dan bertanggung jawab. Pendapat asli daerah merupakan sumber pendapat yang paling penting didalam kompenen utamanya adalah penerimaan yang berasal dari komponen pajak daerah dan retribusi daerah. Pajak daerah berdasarkan undang-undang Nomor 28 Tahun 2009 tentang Pajak Daerah dan Retribusi Daerah adalah kontribusi yang wajib kepada kepala daerah yang terutang oleh orang pribadi atau badan yang bersifat memaksa berdasarkan Undang-undang dengan tidak mendapatkan imbalan secara langsung dan di gunakan untuk kebutuhan daerah tersebut sebagai pembayaran atas jasa atau 
pemberian izin tentu yang khusus disediakan dan/atau diberikan oleh pemerintah daerah untuk kepentingan orang pribadi atau badan.

Undang-undang Nomor 9 tahun 2015 tentang perubahan kedua atas Undang-undang Nomor 23 tahun 2014 tentang Pemerintah Daerah, menjelaskan bahwa tiap-tiap daerah telah diserahkan kewenangannya untuk mengatur dan mengurus rumah tangga sendiri berdasarkan kepentingan masyarakat menurut prakarsa sendiri berdasarkan aspirasi masyarakat dan dalam melaksanakan pembangunan di daerah harus lebih mengutamakan kepentingan masyarakat dan senantiasa bekerjasama antara pemerintah dan masyarakat dalam rangka pembangunan.

Pendapatan daerah dapat berasal dari pendapat asli daerah (PAD) sendiri, pendapatan asli daerah yang berasal dari pembagian dari pendapatan asli daerah, dana perimbangan keuangan antara pemerintah pusat dan daerah, pinjaman daerah dan pinjaman keuangan Daerah yang sah. Selanjutnya pendapatan asli daerah (PAD) terdiri dari pajak daerah dan retribusi daerah, keuntungan perusahaan milik daerah hasil pengelolaan kekayaan daerah dan lain-lain pendapatan asli daerah. Seperti juga pada umumnya, pajak daerah juga mempunyai peranan ganda yaitu sebagai sumber pendapatan daerah (butgetair) dan sebagai pengatur perekonomian daerah ( regulerend ).

Dalam hal-hal tertentu suatu jenis pajak daerah dapat lebih bersifat sebagai suatu pendapatan daerah tetapid apat pula suatu jenis pajak tertentu merupakan alat untuk mengatur alokasi dan distribusi suatu kegiatan ekonomi dalam suatu wilayah atau daerah tertentu ( regulerent). Pada hakekatnya tidak dapat perbedaan yang azasi antara pajak Negara dan pajak daerah mengenai prinsip-prinsip umum khususnya,misalnya mengenai subjek, objek pajak, dan sebagainya yang mendajdi pembedanya adalah mengenai aparat pemungut pajak dan penggunaan pajak, pajak daerah adalah pajak yang dipungut oleh daerah berdasarkan peraturan yang di tetapkan oleh daerah untuk kepentingan rumah tangganya sebagai badan hokum publik.

Maka apa yang tertulis dalam undang-undang pajak Negara dari pemerintah pusat lebih tegas memberi kepentingan masyarakat sebagai pembayar pajak, untuk itu pada tahun 1997 terbitlah undang-undang nomor 18 tahun 1997 tentang pajak daerah dan tertribusi daerah dan dalam pelaksanaan meskipun baru berjalan kurang lebih tiga tahun, Undang-undang perpajakan mengalami perbaikan atau perubahan menjadi undang-undang nomor 34 tahun 2000 tentang perubahan undang-undang nomor 18 tahun 1997 tentang pajak daerah dan retribusi daerah agar dapat menyesuaikan diri dan mengikuti era serta tantangan penyelenggaraan pembangunan dan pemerintahan daerah. Dalam perkembangan selanjutnya kedua Undang-undang tersebut dianggap belum sesuai dengan perkembangan kebijakan otonomi daerah dan aspirasi masyarakat sehingga pada tahun 2009 di undangkan Undangundang Pajak Daerah dan Retribusi Daerah (UU PDRD), Undang-undang tersebut berlaku hingga sekarang dan menjadi pedoman bagi pemerintah daerah dan/atau kota untuk memanfaatkan dan pemberdayaan sumber daya yang berpotensi di Daerah masing-masing untuk meningkatkan pendapatan asli daerah dalam suatu daerah.

Atas hal-hal yang telah diuraikan dalam latar belakang diatas, menjadi pendorong bagi penulis untuk membahas mengenai bagaimana suatu daerah dalam penerapan peraturan daerah untuk meningkatkan pendapatan asli daerah dan akan lebih dibahas dalam penelitian yang dituangkan juga dalam penelitian ini. Adapun yang menjadi permasalahan dalam penelitian ini adalah apa dan bagaimana problematika implementasi Peraturan Daerah Kabupaten Karo Nomor o3 Tahun 2012 tentang Pajak Daerah dalam rangka meningkatkan pendapatan asli daerah? 
Nommensen Journal of Legal Opinion (NJLO)

Jurnal Magister Hukum Program Pascasarjana Universitas HKBP Nommensen

Volume or Nomor o1 Juli 2020 Halaman. 96-112

e-ISSN: 2723-164X p-ISSN: 2722-9858

http://ejournal.uhn.ac.id/index.php/opinion

\section{B. Metode Penelitian}

Dalam menjawab permasalahan sebagaimana yang telah dikemukakan pada bagian terdahulu, maka dilakukan suatu penelitian yang pelaksanaannya menggunakan cara-cara atau metode tertentu. Penelitian hukum dapat dianggap sebagai penelitian ilmiah apabila memenuhi kriteria berikut : Didasarkan pada metode, sistematika, dan logika tertentu; Bertujuan untuk mempelajari gejala hukum tertentu (data primer) dan data sekunder; Guna mencari solusi atas permasalahan yang timbul dari gejala yang diteliti tersebut.

Penelitian hukum didasarkan pada metode, artinya semua kegiatan yang meliputi persiapan penelitian, proses penelitian, dan hasil penelitian menggunakan cara-cara yang secara umum diakui dan berlaku pada ilmu pengetahuan. Adapun langkah- langkah yang penulis tempuh dalam melakukan penelitian ini adalah Pendekatan masalah yang dipergunakan dalam penelitian ini menggunakan dua cara yaitu Pendekatan normatif, yang dilakukan dengan cara mempelajari kaidah-kaidah hukum yang terdapat dalam buku-buku literatur, perundang-undangan yang berlaku dan berhubungan dengan penelitian ini. Pendekatan empiris, pendekatan yang dilakukan dengan cara melihat atau memperhatikan peristiwa yang terjadi di lapangan.

Penelitian merupakan aktivitas ilmiah yang sistematis, terarah dan bertujuan, maka data yang dikumpulkan harus relevan dengan permasalahan yang dihadapi. Data yang diperlukan dalam penelitian ini terdiri dari 2 (dua) jenis yaitu sekunder dan primer, yang sumbemya masing-masing sebagai berikut data Sekunder, yaitu data yang berupa bahan pustaka, bukubuku yang ada hubungannya dengan permasalahan yang sedang penulis teliti data primer, yaitu data lapangan yang dikumpulkan penulis secara langsung dari pihak-pihak terkait dengan masalah yang diteliti. Adapun alat pengumpulan data yang penulis pergunakan dalam penelitian ini studi pustaka, studi ini dilakukan untuk mendapatkan data sekunder, yang dilakukan dengan jalan mempelajari, menelaah dan mengutip data dari berbagai buku literatur dan peraturan perundang-undangan yang berlaku dan mempunyai hubungan dengan masalah yang dibahas dalam penelitian ini. Studi lapangan, studi ini dilakukan untuk mendapatkan data primer, dengan cara observasi dan wawancara. Observasi dimaksud adalah pengamatan dan pencatatan data yang diperlukan di Iokasi penelitian. Sedangkan wawancara adalah proses tanya jawab secara langsung dengan pihak-pihak terkait dalam penelitian ini. Sebelum melakukan wawancara, terlebih dahulu dipersiapkan daftar pertanyaan yang bersifat garis besar sebagai pedoman dalam melakukan wawancara.

Dari keseluruhan data yang telah terkumpul kemudian diperiksa kembali dengan maksud untuk mengetahui apakah data-data yang diperlukan sudah lengkap dan jelas dengan cara editing (pemeriksaan data), coding (penandaan data), dan penyusunan data. Editing atau pemeriksaan data, yaitu pembenaran apakah data yang terkumpul melalui studi pustaka, dokumen, wawancara, dan koesioner sudah dianggap lengkap, relevan, jelas tidak berlebihan dan tanpa kesalahan. Penyusunan atau sistematisasi data yaitu kegiatan menabulasi secara Sistematis data yang sudah di edit dan diberi tanda itu dalam bentuk tabel-tabel yang berisi angka-angka dan persentase bila data itu kualitatif. Dari keseluruhan data yang telah diolah dari hasil studi kepustakaan dan studi lapangan, maka kegiatan terakhir yang perlu dilakukan adalah menganalisis data. Adapun analisis data yang penulis gunakan adalah analisis kualitatif yaitu dengan cara menguraikan data dari hasil dilapangan, yang selanjutnya diadakan pembahasan terhadap masalah yang diteliti, sehingga memudahkan untuk menarik kesimpulan dalam menjawab permasalahan. 
Nommensen Journal of Legal Opinion (NJLO)

Jurnal Magister Hukum Program Pascasarjana Universitas HKBP Nommensen

Volume o1 Nomor o1 Juli 2020 Halaman. 96-112

e-ISSN: 2723-164X p-ISSN: 2722-9858

http://ejournal.uhn.ac.id/index.php/opinion

\section{Pembahasan}

\section{Tinjauan Umum tentang Pajak}

Kewajiban dari suatu Negara adalah melayani kebutuhan dari masyarakatnya. Dalam penyelenggaraan berbagai tugas yang berguna untuk masyarakat tersebut sudah tentu diperlukan biaya, karna tanpa biaya maka Negara tidak mungkin melaksanakan tugas-tugas tersebut dengan sempurna. Dalam zaman modern sekarang ini biaya yang dimaksud identik dengan uang, walaupun terdapat kekecualian dalam hal pembiayaan dibantu secara materil oleh pihak-pihak tertentu, untuk mendapatkan uang, selain mencetak sendiri atau meminjam dari luar negeri banyak jalan yang ditempu oleh pemerintah. Salah satu jalan yang ditempu oleh pemerintah dalam mengumpulkan biaya untuk menjalankan tugas-tugas Negara tersebut adalah dengan cara memungut pajak dari masyarakat. Pajak pada mulanya merupakan suatu upeti (pemberian secara cuma-cuma) namun sifatnya merupakan suatu kewajiban yang dapat dipaksakan yang harus dilaksanakan oleh rakyat (masyarakat) kepada seorang raja atau penguasa. Rakyat ketika itu memberikan upetinya kepada raja atau penguasa berbentuk natura berupa padi, ternak atau hasil tanaman lainnya seperti pisang, kelapa dan lain-lainnya.

Pemberian yang dilakukan rakyat saat itu digunakan untuk keperluan atau kepentingan raja atau penguasa setempat. Sedangkan imbalan atau prestasi yang dikembalikan kepada rakyat tidak ada, oleh karena memang sifatnya hanya untuk kepentingan sepihak dan seolaholah ada tekanan secara psikologi karna kedudukan raja yang lebih tinggi status sosialnya dibandingkan rakyat. Namun, dalam perkembangannya, sifat upeti yang diberikan oleh rakyat tidak lagi hanya kepentingan raja saja, tetapi sudah mengarah kepada kepentingan rakyat itu sendiri. Sejarah singkat perpajakan di Indonesia sudah dimulai dari adanya kerajaan-kerajaan di Indonesia, yang pemungutannya dilakukan dalam bentuk pajak tanah, pajak barang dagangan, upeti yang diberikan pada raja atau penguasa. Hasil pajak yang diterima oleh raja digunakan untuk penyelenggaraan pemerintah setempat, membiayai pertahanan kekuatan raja, sehingga rakyat mendapatkan pelayanan jaminan ketertiban keamanan. Kemudian berkembangke zaman kedatangan VOC yang menggunakan pajak : usaha, rumah dan pajak kepala kepada para pedagang, pajak penjualan barang dipasar. Yang perlu diingat bahwa pada zaman penjajahan pajak itu diekpolitasikan untuk si penjajah guna mengisi pundi-pundi kas pemerintahan si penjajah, sedangkan rakyat Indonesia tidak merasakan dampak dari pemungutan pajak itu sendiri.

Berbicara mengenai pajak, latar belakang yuridis pemungutan pajak di Indonesia adalah berdasarkan kepada Amandemen Undang-Undang Dasar 1945 Indonesia pasal 23a yang menyatakan bahwa pajak dan pungutan lain yang bersifat memaksa untuk keperluan Negara diatur dengan undang-undang. Undang-undang yang mengatur mengenai ketentuan umum dan tata cara perpajakan di Indonesia awalnya dimulai dari tahun 1983 sampai tahun 2007. Undang-undang perpajakan sendiri tidak memberikan defenisi pajak sampai dengan dikeluarkannya Undang-undang Nomor 28 Tahun 2007 tentang Perubahan Ketiga atas Undang-Undang Nomor 6 Tahun 1983 tentang Ketentuan Umum dan Tata Cara Perpajakan. Adapun Pengertian pajak menurut Undang-undang Nomor 28 Tahun 2007 tentang Perubahan Ketiga atas Undang-Undang Nomor 6 Tahun 1983 tentang Ketentuan Umum dan Tata Cara Perpajakan adalah kontribusi wajib kepada negara yang terutang oleh orang pribadi atau badan yang bersifat memaksa berdasarkan Undang-Undang, dengan tidak mendapatkan imbalan secara langsung dan digunakan untuk keperluan negara bagi sebesar-besamya kemakmuran rakyat.

Selain pengertian pajak menurut Undang-Undang Nomor 28 Tahun 2007 tentang Perubahan Ketiga atas Undang-undang Nomor 6 Tahun 1983 tentang Ketentuan Umum dan 
Tata Cara Perpajakan terdapat bermacam-macam batasan atau defenisi tentang "pajak" yang dikemukakan oleh para ahli diantaranya adalah:

1. Defenisi Prancis, termuat dalam buku Leroy Beaulieau, Traite de la Science des Finances, 1906, pajak adalah bantuan,baik secara langsung maupun tidak yang dipaksakan oleh kekuasaan publik dari penduduk atau dari barang, untuk menutupi belanja pemerintah.

2. Menurut N. J. Feldeman dalam buku De Overheidsmiddelen Van Indonesia, Leiden. 1949 berbunyi pajak adalah prestasi yang dipaksakan sepihak Oleh dan terutang kepada penguasa menurut norma-norma yang ditetapkannya secara umum tanpa adanya kontraprestasi dan semata-mata digunakan untuk menutup pengeluaran- pengeluaran umum.

3. Menurut M. J. H. Smeets dalam bukunya De Economische Betekenis der Belastingen , 1951 berbunyi pajak adalah prestasi kepada pemerintah yang terutang melalui norma-norma umum, yang dapat dipaksakan tanpa ada kalanya kontraprestasi yang dapat ditunjukkan dalam hal yang individual, maksudnya adalah untuk membiayai pengeluaran pemerintah.

4. Menurut Soeparman Soemahamidjaja dalam desertasinya yang trrjudul "Pajak Berdasarkan Azas Gotong Royong", Universitas Padjadjaran, Bandung, 1964 pengertian pajak adalah "iuran wajib, berupa uang atau barang, yang dipungut oleh penguasa berdasarkan normanorma hukum, guna menutup biaya produksi barang- barang dan jasa-jasa kolektif dalam mencapai kesejahteraan umum".

5. Menurut P. J. A. Adriani pajak adalah iuran masyarakat kepada Negara (yang dapat dipaksakan) yang terutang oleh yang wajib membayarnya menurut peraturan- peraturan umum (undang-undang) dengan tidak mendapat prestasi kembali yang langsung dapat ditunjuk dan yang gunanya adalah untuk membiayai pengeluaran- pengeluaran umum berhubung tugas Negara untuk menyelenggarakan pemerintah.

6. Menurut H. Rochmat Soemitro pajak adalah iuran rakyat kepada kas Negara berdasarkan undang-undang (yang dapat dipaksakan) dengan tiada mendapat jasa timbal (kontra prestasi) yang langsung dapat ditunjukkan dan yang digunakan untuk membayar pengeluaran umum. Defenisi tersebut kemudian dikoreksinya yang berbunyi sebagai berikut: pajak adalah peralihan kekayaan dari pihak rakyat kepada kas Negara untuk membiayai pengeluaran rutin dan surplusnya digunakan untuk public saving yang merupakan sumber utama untuk membiayai public investment.

7. Menurut Sommerfeld Ray M., Anderson HerscheI M., dan Brock Horace R pajak adalah suatu pengalihan sumber dari sektor swasta ke sektor pemerintah bukan akibat pelanggaran hukum, namun waiib dilaksanakan, berdasarkan ketentuan yang ditetabkan lebih dahulu, tanpa mendapat imbalan yang langsung dan proporsional, agar pemerintah dapat melaksanakan tugas-tugasnya untuk menjalankan pemerintahan.

Pajak dari perspektif ekonomi dipahami sebagai beralihnya sumber daya dari sektor swasta kepada sektor publik. Pemahaman ini memberikan gambaran bahwa adanya pajak menyebabkan dua situasi merjadi berubah. Pertama, berkurangnya kemampuan individu dalam menguasai sumber daya untuk kepentingan penguasaan barang dan jasa. Kedua, bertambahnya kemampuan keuangan Negara dalam penyediaan barang dan jasa publik yang merupakan kebutuhan masyarakat. Sementara pemahaman pajak dari perspektif hukum menurut Soemitro merupakan suatu perikatan yang timbul karena adanya undang-undang yang menyebabkan timbulnya kewajiban warga negara untuk menyetorkan sejumlah penghasilan tertentu kepada negara, negara mempunyai kekuatan untuk memaksakan dan uang pajak tersebut harus dipergunakan untuk penyelenggaraan pemerintahan. Dari pendekatan hukum ini memperlihatkan bahwa pajak yang dipungut harus berdasarkan 
undang-undang sehingga menjamin adanya kepastian hukum, baik bagi fiskus sebagai pengumpul pajak maupun wajib pajak sebagai pembayar pajak.

Dari berbagai defenisi yang diberikan terhadap pajak baik pengertian secara ekonomis (pajak sebagai pengalihan sumber daya sektor swasta ke sektor pemerintah) atau pengertian secara yuridis ( pajak adalah iuran ymg dapat dipaksakan) dapat ditarik kesimpulan tentang ciri-ciri yang terdapat pada pengertian pajak antara lain sebagai berikut :

1. Pajak dipungut oleh negara baik oleh pemerintah pusat maupun pemerintah daerah berdasarkan atas undang-undang serta aturan pelaksanaannya.

2. Pemungutan pajak mengisyaratkan adanya alih dana (sumber daya) dari sektor swasta (wajib pajak membayar pajak) ke sektor Negara (pemungut pajak / administrator pajak).

3. Pemungutan pajak diperuntukkan bagi keperluan pembiayaan umum pemerintah dalam rangka menjalankan fungsi pemerintahan, baik rutin maupun pembangunan.

4. Tidak dapat ditunjukkan adanya imbalan (kontra prestasi) individual oleh pemerintah terhadap pembayaran pajak yang dilakukan oleh para wajib pajak.

5. Selain fungsi budgeter (anggaran) yaitu fungsi mengisi Kas Negara / Anggaran Negara yang diperlukan untuk menutup pembiayaan penyelenggaraan pemerintahan, pajak juga berfungsi sebagai alat untuk mengatur atau melaksanakan kebijakan Negara dalam lapangan ekonomi dan social (fungsi mengatur / regulatif).

Di Negara-negara hokum segala sesuatu harus ditetapkan dalam undang-undang seperti di Indonesia pemungutan pajak diatur dalam Pasal 23A Undang-undang Dasar Negara Republik Indonesia 1945 yang berbunyi "pajak dan pungutan lain yang bersifat memaksa untuk keperluan Negara diatur dengan undang-undang", Ada beberapa hal yang perlu diperhatikan dalam penyusunan undang-undang tentang pajak, yaitu :

1. Pemungutan pajak yang dilakukan oleh Negara yang berdasarkan undang-undang tersebut haru dijamin kelancarannya.

2. Jaminan hukum bagi para wajib pajak untuk tidak diperlukan secara umum.

3. Jaminan hukum akan terjaganya kerahasiaan bagi para wajib pajak.

\section{Asas Pemungutan Pajak dan Asas Pengenaan Pajak}

Dalam Undang-undang nomor 28 tahun 2007 tentang Perubahan Ketiga atas Undangundang Nomor 6 Tahun 1983 tentang Ketentuan Umum dan Tata Cara Perpajakan tidak diatur mengenai asas-asas pemungutan pajak, tetapi dalam abad ke 18, Adam Smith(1723-1790) dalam bukunya An Inquiry into the Nature and Causes of the Wealth of Nations yang lebih terkenal dengan nama Wealth of Nations melancarkan ajarannya sebagai asas pemungutan pajak. Asas pemungutan pajak dari Adam Smith tersebut dinamainya "The Four Maximas" yang dapat diuraikan sebagai berikut :

1. Asas Equality. Pembagian tekanan pajak di antara subjek pajak masing-masing hendaknya dilakukan secara seimbang dengan kemampuannya dalam arti harus seimbang dengan penghasilan yang dinikmati oleh masing-masing subjek pajak, dibawah perlindungan pemerintah (disebut juga asas pembagian/asas kepentingan). Dalam asas "Equality" ini, suatu Negara tidak boleh mengadakan suatu diskriminasi diantara sesame wajib pajak. Dalam keadaan yang sama, para wajib pajak harus dikenakan pajak yang sama pula. Asas ini disebut juga asas keadilan dalam pemungutan pajak.

2. Asas Certainty. Pajak yang dibayar oleh seseorang (wajib pajak) harus pasti (terang/certain) dan tidak mengenal kompromis (not arbitrary) antara wajib pajak dengan petugas pajak. Dalam asas certainty ini, kepastian hukum yang di pentingkan adalah mengenai subjek, objek, besarnya pajak dan ketentuan mengenai waktu pembayaran. Asas certainty merupakan asas yuridis dalam pemungutan pajak. 
3. Asas convenient. Pajak hendaknya dipungut pada saat yang paling baik bagi para wajib pajak yaitu pada saat para wajib pajak sedang mempunyai uang untuk membayar pajak. Asas convenient ini merupakan asas financial dalam pemungutan pajak.

4. Asas Efisiensi. Asas ini menetapkan bahwa pemungutan pajak hendaknya dilakukan sehemat-hematnay, dengan kata lain jangan sampai biaya pemungutan pajak tersebut melebihi jumlah pajak yang dapat dihasilkan. Asas efesiensi ini sering juga disebut asas ekonomis dalam pemungutan pajak.

Selain asas pemungutan pajak ada juga asas pengenaan pajak. Terdapat beberapa asas yang dapat dipakai oleh Negara sebagai asas dalam mentukan wewenangnya untuk mengenakan pajak, khusunya untuk pengenaan pajak penghasilan. Asas utama yang paling sering digunakan oleh Negara sebagai landasan untuk mengenakan pajak adalah :

1. Asas Domisili atau disebut juga asas kependudukan (domicile/residence), berdasarkan asas ini Negara akan mengenakan pajak atas suatu pengahasilan yang diterima atau diperoleh orang pribadi atau badan, apbila untuk kepentingan perpajakan, orang pribadi tersebut merupakan penduduk (resident) atau berdomisili di Negara itu atau apabila badan yang bersangkutan berkedudukan di Negara itu. Dalam kaitan ini, tidak dipersoalkan dari mana pengahasilan yang akan dikenakan pajak itu berasal. Itulah sebabnya bagi Negara yang menganut asas ini, dalam system pengenaan pajak terhadap penduduknya akan mengabungkan asas domisili (kependudukan) dengan konsep pengenaan pajak atas penghasilan baik yang diperoleh dinegara itu maupun pengahasilan yang diperoleh di luar negeri (world-wide income soncept).

2. Asas sumber, Negara yang menganut asas sumber akan mengenakan pajak atas suatu penghasilan yang diterima atau diperoleh orang pribadi atau badan hanya apabila penghasilan yang akan dikenakan pajak itu diperoleh atau diterima oleh orang pribadi tau badan yang bersangkutan dari sumber-sumber yang berada dinegara itu. Dalam asas ini, tidak menjadi persoalan mengenai siapa dan apa status dari orang atau badan yang memperoleh penghasilan tersebut sebab yang menjadi landasan pengenaan pajak adalah objek pajak yang timbul atau berasal dari Negara itu. Contoh : tenaga kerja asing bekerja di Indonesia maka dari pengahasilan yang di dapat di Indonesia akan dikenakan pajak oleh pemerintah Indonesia.

3. Asas kebangsaan atau asas nasionalitas atau disebut juga asas kewarganegaraan (nationality/citizenship principle). Dalam asas ini, yang menjadi landasan pengenaan pajak adalah status kewarganegaraan dari orang atau badan yang memperoleh penghasilan. Berdasarkan asas ini, tidaklah menjadi persoalan dari mana pengahasilan yang akan dikenakan pajak berasal. Seperti halnya dalam asas domisili, sistem pengenaan pajak berdasarkan asas nasionalitas ini dilakukan dengan cara mengabungkan azas nasionalitas dengan konsep pengenaan pajak atas world wide income.

Pajak mempunyai peranan yang sangat penting dalam kehidupan bernegara, khususnya di dalam pelaksanaan pembangunan karena pajak merupakan sumber pendapatan Negara untuk membiayai semua pengeluaran termasuk pengeluaran pembangunan. Dengan demikian, fungsi finansial pajak merupakan sumber dana bagi pemerintah (apabila untuk saat ini, pajak sumber dana bagi pemerintah yang paling utama, dikarenakan dimulai berkurangnya sumber dana lainnya yang dimiliki pemerintah, misalnya : minyak dan gas bumi), guna mendapatkan uang sebanyak banyaknya untuk pengeluaran pemerintah dan pembangunan Negara.

\section{Prinsip dan Kriteria Perpajakan Daerah}

Kemandirian suatu daerah sangat ditentukan oleh upaya daerah dalam menggali dan meningkatkan sumber-sumber keuangan sendiri. Salah satu masalah yang dihadapi daerah 
dalam meningkatkan Pendapatan Asli Daerah adalah kelemahan dalam pengukuran atau penilaian atas pungutan daerah. Untuk mendukung upaya upaya peningkatan PAD perlu diadakan pengukuran atau penilaian dan penetapan kriteria-kriteria penetapan sumbersumber PAD khususnya pajak daerah dan retribusi daerah agar dapat dipungut secara berkesinambungan tanpa memperburuk alokasi faktor-faktor produksi dan keadilan. Prinsip dan kriteria perpajakan daerah tidak jauh berbeda dengan kriteria pajak secara umum, yang membedakan keduanya adalah pihak pemungutnya.

Pajak umum yang memungutnya adalah Pemerintah Pusat, sedangkan pajak daerah yang memungutnya adalah Pemerintah Daerah. Prinsip-prinsip umum perpajakan daerah pada dasarnya sama dengan sistem perpajakan yang dianut oleh kebanyakan negara di dunia, yaitu harus memenuhi kriteria umum tentang perpajakan (Sidik, 2002: 2), sebagai berikut :

1. Prinsip memberikan pendapatan yang cukup dan elastis, artinya dapat mudah naik turun mengikuti naik/turunnya pendapatan masyarakat.

2. Adil dan merata secara vertikal artinya sesuai dengan tingkat kelompok masyarakat sehingga tidak ada yang kebal pajak.

3. Administrasi yang fleksibel artinya sederhana, mudah dihitung, pelayanan memuaskan bagi wajib pajak.

4. Secara politis dapat ditermia oleh masyarakat, sehingga timbul motivasi dan kesadaran pribadi untuk membayar pajak.

5. Non-distorsi terhadap perekonomian : implikasi pajak atau pungutan yang hanya menimbulkan pengaruh minimal terhadap perekonomian. Pada dasarnya setiap pajak atau pungutan akan menimbulkan suatu beban baik bagi konsumen maupun produsen. Jangan sampai suatu pajak atau pungutan menimbulkan beban tambahan (extra burden) yang berlebihan, sehingga akan merugikan masyarakat serta menyeluruh (dead-weight loss).

Kriteria pajak daerah secara spesifik diuraikan oleh K.J. Davey (1988:39) yang terdiri dari 4 (empat) hal yaitu :

1. Pajak yang dipungut oleh pemerintah daerah berdasarkan pengaturan dari daerah sendiri

2. Pajak yang dipungut berdasarkan peraturan pemerintah pusat tetapi penetapan tarifnya dilakukan oleh pemerintah daerah

3. Pajak yang ditetapkan atau dipungut oleh pemerintah daerah

4. Pajak yang dipungut dan diadministrasikan oleh pemerintah pusat tetapi hasil pungutannya diberikan kepada pemerintah daerah.

Dalam Undang-Undang Republik Indonesia No. 28 Tahun 2009 Tentang Pajak Daerah dan Retribusi Daerah disebutkan kriteria-kriteria pajak daerah sebagai berikut :

1. Bersifat pajak dan bukan retribusi, artinya bahwa pajak yang ditetapkan harus sesuai dengan pengertian pajak.

2. Objek pajak terletak atau terdapat di wilayah Daerah Kabupaten/Kota yang bersangkutan dan mempunyai mobilitas yang cukup rendah serta hanya melayanai masyarakat di wilayah Daerah Kabupaten/Kota yang bersangkutan.

3. Objek dan dasar pengenaan pajak tidak bertentangan dengan kepentingan umum, artinya bahwa pajak tersebut dimaksudkan untuk kepentingan bersama yang lebih luas anatara pemerintah dan masyarakat dengan memperhatikan aspek ketentraman, dan kestabilan politik, ekonomi, sosial, budaya, pertahanan dan keamanan.

4. Objek pajak bukan merupakan objek pajak propinsi dan/atau objek pajak pusat.

5. Potensi memadai, artinya bahwa hasil pajak cukup besar sebagai salah satu sumber pendapatan daerah dan Iaju pertumbuhannya diperkirakan sejalan dengan laju pertumbuhan ekonomi daerah. 
6. Tidak memberikan dampak ekonomi yang negatif, artinya bahwa pajak tidak mengganggu alokasi sumber-sumber ekonomi secara efisien dan tidak merintangi arus sumber daya ekonomi anat daerah maupun kegiatan ekspor impor.

7. Memperhatikan aspek keadilan dan kemampuan masyarakat, antara lain objek dan subjek pajak harus jelas sehingga dapat diawasi pemungutannya, jumlah pembayaran pajak dapat diperkirakan oleh wajib pajak yang bersangkutan, dan tarif pajak ditetapkan dengan memperhatikan keadaan wajib pajak. Sedangkan kemampuan masyarakat maksudnya adalah kemampuan subjek pajak untuk memikul tambahan beban pajak.

8. Menjaga kelestarian lingkungan, artinya bahwa pajak harus bersifat netral terhadap lingkungan, yang berarti pengenaan pajak tidah memberikan peluang kepada pemerintah daerah dan masyarakat untuk merusak lingkungan yang akan menjadi beban bagi pemerintah daerah dan masyarakat.

\section{Pelaksanaan Perolehan Pajak Daerah Kabupaten Karo}

Kewenangan pemungutan pajak daerah di Kabupaten Karo dilaksanakan oleh Badan Pengelola Keuangan Pendapatan Dan Aset Daerah Kabupaten Karo yang didirikan berdasarkan Peraturan Daerah Kabupaten Karo No. 05 Tahun 2016, dengan dasar evaluasi:

1. Peraturan Pemerintah No. 41 Tahun 2007 tentang Organisasi Perangkat Daerah

2. Peraturan Menteri Dalam Negeri No. 56 Tahun 2010 tentang Petunjuk Teknis Penataan Organisasi Perangkat Daerah

Dinas Pendapatan Pengelolaan Keuangan Dan Aset (DP2KA) menjadi Badan Pengelolaan Keuangan Pendapatan dan Aset Daerah (BPKPAD), dengan dasar evaluasi: Peraturan Menteri Dalam Negeri No. 56 Tahun 2010 tentang Perubahan atas Peraturan Menteri Dalam Negeri No. 57 Tahun 2007 tentang Petunjuk Teknis Penata Organisasi Dinas Pendapatan Pengelolaan Keuangan Dan Aset (DP2KA) menjadi Dinas Pendapatan Daerah (Dispenda) dan Badan Pengelolaan Keuangan dan Aset (BPKA), dengan dasar evaluasi:

1. Peraturan Menteri Dalam Negeri No. 56 Tahun 2010 tentang Perubahan atas Peraturan Menteri Dalam Negeri No. 57 Tahun 2007 tentang Petunjuk Teknis Penataan Organisasi Perangkat Daerah pada Lampirannya menyebutkan pelimpahan kewenangan dibidang perpajakan Bea Perolehan Hak Atas dan Bangunan (BPHTB) sebagai Pajak Daerah dan Pajak Bumi Bangunan (PBB) diserahkan pada Pemerintah Daerah.

2. Peraturan Bersama Menteri Keuangan dan Menteri Dalam Negeri No 186/PMK.o7/2010 No. 53 Tahun 2010 tentang Tahapan Persiapan Pengalihan Bea Perolehan Hak atas Tanah dan Bangunan sebagai pajak daerah. Susunan Organisasi dan Tata Kerja Dispenda Kabupaten KaroUtara, berdasarkan Peraturan Daerah Kabupaten KaroUtara No. 21 Tahun 2011 tentang Pembentukan Organisasi dan Tata Kerja Perangkat Daerah, maka dapat terlihat, sebagaimana dalam gambar berikut.

Berdasarkan Pasal 24 Peraturan Bupati Karo Nomor 40 Tahun 2016 Tentang Tugas Pokok Fungsi dan Uraian Tugas Badan Daerah, adapun tugas pokok BPKPAD Kab. Karo adalah Sebagai Berikut :

1. Penyusunan kebijakan teknis sesuai dengan lingkup tugasnya.

2. Pelaksanaan tugas dukungan teknis sesuai dengan lingkup tugasnya.

3. Pemantauan, evaluasi dan laporan pelaksanaan tugas kedudukan teknis sesuai dengan tugasnya

4. Pembinaan teknis penyelenggaraan fungsi-fungsi penunjang urusan

5. Pelaksanaan fungsi lain yang di berikan oleh Bupati sesuai dengan tugas dan fungsinya. 
http://ejournal.uhn.ac.id/index.php/opinion

Hasil Penerimaan perolehan Pajak Daerah Daerah di Kabupaten karo dapat dilihat berdasarkan jenis pungutan yang akan ditampilkan Hasil realisasi penerimaan Pajak Daerah Kabupaten KaroUtara Tahun 2017 adalah sebagaimana tampak pada table berikut ini.

Tabel Realisasi Penerimaan Pajak Daerah Tahun 2017

\begin{tabular}{|l|l|l|l|l|l|}
\hline No & \multicolumn{1}{|c|}{$\begin{array}{c}\text { Jenis } \\
\text { Penerimaan }\end{array}$} & \multicolumn{1}{|c|}{ Target (Rp) } & \multicolumn{1}{|c|}{ Realisasi (Rp) } & \multicolumn{1}{|c|}{ Sisa (Rp) } & $\%$ \\
\hline 1 & Pajak Hotel & Rp.4.855.600.000.00 & Rp.5.665.532.999.00 & Rp.809.932.999.00 & $116.68 \%$ \\
\hline 2 & Pajak Restoran & Rp.2.651.453.000.00 & Rp.3.371.503.800.00 & Rp.720.050.800.00 & $100.00 \%$ \\
\hline 3 & Pajak Hiburan & Rp.2.977.600.000.00 & Rp.3.260.876.971.00 & Rp.283.276.971.00 & $109.51 \%$ \\
\hline 4 & $\begin{array}{l}\text { Pajak Penerangan } \\
\text { Jalan }\end{array}$ & Rp.10.942.426.400.00 & Rp.12.042.769.061.00 & Rp.1.100.342.661.00 & $110.06 \%$ \\
\hline 5 & $\begin{array}{l}\text { Pajak Bumi dan } \\
\text { Bangunan } \\
\text { Pedesaan dan } \\
\text { Perkotaan }\end{array}$ & Rp.5.481.453.000.00 & Rp.5.436.828.781.00 & Rp.44.624.219.00 & $99.19 \%$ \\
\hline 6 & Pajak Parkir & Rp.627.696.000.00 & Rp.502.200.000.00 & Rp.125.496.000.00 & $80.01 \%$ \\
\hline & Jumlah & Rp.27.536.228.400.00 & Rp.30.279.711.612.00 & Rp.3.083.723.650 & \\
\hline
\end{tabular}

Sumber BPKPAD Kab.Karo

Realisasi Pajak Daerah untuk tahun 2017 adalah sebesar Rp. 30.279.711.612.oo,- melebihi dari target sebelumnya yaitu sebesar Rp.3.083.723.650,- dari yang telah ditetapkan sebesar Rp. 27.536.228.400.00,-, sehingga pencapaian target mencapai sebesar 100.00\%. Hal ini terjadi dikarenakan penerimaan Pajak Daerah yang dapat mencapai target pada tahun 2017 yaitu Pajak Hotel sebesar Rp. 5.665.532.999.00,- dengan persentasi 100,00\%, Pajak Restoran Rp. 3.371.503.800.00,-, dengan persentase $100.00 \%$, sehingga pencapaian target hanyalah $100.00 \%$, pajak hiburan Rp. 3.260.876.971.00,- melebihi dari target sebesar Rp. 2.977.600.00o.oo,- pajak penerangan jalan Rp. 12.042.769.061.00 - melebihi dari target sebesar Rp. 10.942.426.400.00 dan yang tidak memenuhi target pada tahun 2017 adalah Pajak Bumi dan Bangunan Perdesaan dan Perkotaan Rp. 5.436.828.781.0o,- dengan persentase 99.19\%, adapun kendala sehingga tidak tercapainya target pada pajak bumi dan bangunan pedesaan dan perkotaan adalah kurangnya minat masyarakat khususnya masyarakat yang ada di desa didalam membayar pajak.

Untuk mengatasi hal tersebut perlu diambil suatu kebijakan oleh Pemerintah Daerah Kabupaten Karo dalam rangka peningkatan penerimaan daerah yaitu melalui :

1. Penyuluhan kepada wajib Pajak.

2. Peningkatan Tertib Administrasi

3. Pendataan obyek pajak dan retribusi yang meliputi seluruh wilayah Kabupaten karo.

4. Intensifikasi pemungutan

5. Peningkatan Pengawasan pelaksanaan pemungutan

6. Peningkatan koordinasi dengan semua unit pengelolaan pendapatan daerah.

\section{Problem Pelaksanaan Perolehan Pajak Daerah di Kabupaten Karo}

Hambatan yang selalu timbul dalam pelaksanaan perolehan pajak daerah dalam suatu sistem perpajakan adalah kesulitan menciptakan sistem yang dapat menghasilkan suatu pengertian yang baik antara masyarakat sebagai pembayar pajak dan pemerintah selaku pembuat undang-undang dan peraturan perpajakan. Pemerintah selaku fiskus pajak merencanakan dan menggodok undang-undang perpajakan atas dasar dan prinsip perpajakan yang seadil-adilnya, yang memliki nilai dan manfaat bagi masyarakat maupun bagi negara itu sendiri.

Dalam melaksanakan tugasnya selaku perancang dan pembuat undang-undang perpajakan, pemerintah harus membuat peraturan itu sedemikian rupa sehingga mudah 
dimengerti. Jika produk peraturan yang dibuat sulit dimengerti oleh masvarakat, otomatis akan timbul suatu bentuk perlawanan pajak, yang cara bentuk dan dalihnya bisa bermacammacam. Mengamati secara umum tentang hambatan mengenai pemungutan pajak daerah dan retribusi daerah dapat diprediksikan dan diungkapkan melalui pemikiran secara universal, yakni:

1. Tentang tarif pemungutan pajak daerah dan retribusi daerah seperti dalam UndangUndang Nomor 28 Tahun 2009 tentang Perubahan Atas Undang Undang Nomor 34 Tahun 2000 tentang Pajak Daerah dan Retribusi Daerah pada Pasal 3 ayat (1) huruf e sampai k, dengan tarif sebagai berikut :
a. Pajak Hotel
$10 \%$
b. Pajak Restoran
$10 \%$
c. Pajak Hiburan
$15 \%$
d. Pajak Reklame
$25 \%$
e. Pajak Penerangan Jalan
$10 \%$
f. Pajak Pengambilan dan Pengolahan Bahan Gol C $\quad 20 \%$
g. Pajak Parkir
$20 \%$

h. Tentang tanggung jawab (accountability) pemerintah daerah dalam mengelola dan memanfaatkan pajak daerah. Pajak daerah dipungut berdasarkan penetapam kepala Daerah dengan menggunakan Surat Ketetapan Pajak Daerah (SKPD) dan, atau dokumen lain yangg dipersamakan. Untuk melakukan pembayaran pajak daerah menggunakan Surat Setoran Pajak Daerah (SSPD) dan, pembayaran dilakukan pada Kantor Pos atau Bank Persepsi, Bank umum yang ditunjuk oleh Bendahara Umum Negara (BUN)/ Kuasa BUN untuk menerima setoran penerimaan Negara bukan pajak dalam rangka ekspor dan impor yang meliputi penerimaan pajak, cukai dalam negeri dan penerimaan bukan pajak. Jika wajib pajak dan tidak membayar akan ditagih dengan menggunakan Surat Tagihan Pajak Daerah STPD).

Disisi lain hambatan-hambatan terhadap pemungutan pajak dapat dikelompokkan menjadi :

Perlawanan pasif.

Masyarakat enggan (pasif) membayar pajak, yang dapat disebabkan antara lain:

1. Perkembangan intelektual dan moral masyarakat

2. Sistem perpajakan yang mungkin sulit dipahami masyarakat

3. Sistem kontrol tidak dapat dilakukan atau dilaksanakan dengan baik

Perlawanan aktif

Perlawanan aktif meliputi semua usaha dan perbuatan yang secara langsung ditujukan kepada fiskus dengan tujuan untuk menghindari pajak. Bentuknya antara lain:

1. Tax avoidance, usaha meringankan beban pajak dengan melanggar undang undang.

2. Tax evasion, usaha meringankan beban pajak dengan cara melanggar undang-undang (menggelapkan pajak).

Faktor-faktor yang menjadi hambatan dalam pelaksanaan perolehan pajak daerah teradapat beberapa fdaktor hambatan teknis dalam bentuk: kesiapan (kuantitatif/kualitatit) para fiskus, dokumentasi tentang obyek dan subjek pajak, sarana dan prasarana pendukung, persoalan internal obyek pajak (kesadaran, kesiapan, waktu yang tepat), kondisi geografis dll Tentang sanksi, penyesuaian tariff dan kinerja aparat birokrasi yang lemah Ditemukan sesuai dengan data penelitian dimana terdapat beberapa faktor kendala teknis dalam bentuk kesiapan (kuantitatif/kualitatif) para fiskus, dokumentasi tentang subjek dan obyek pajak, sarana dan prasarana pendukung, persoalan internal obyek pajak (kesadaran, kesiapan waktu yang tepat). Bila dianalisis dengan menggunakan teori kesadaran/budaya hukum oleh Satjipto 
Rahardjo (1980: 144) diketahui bahwa terdapat persoalan potensial mengenai daerah terdapat beberapa faktor hambatan Sanksi, penyesuaian tarif dan kinerja aparat birokrasi yang lemah.

Kendala-kendala yang dihadapi Pemerintah daerah khususnya Badan pengelola Keuangan Pendapatan Dan Aset Daerah Kabupaten Karo dalam melakukan Pemungutan pajak berdasarkan Peraturan daerah Nomor 03 Tahun 2012 yang secara teknis dapat diungkap antara lain:

1. Tentang sanksi, sering terdapat kendala untuk menerapkan sanksi pada wajib pajak yang sekarang hanya dilakukan dengan menyampaikan surat teguran / peringatan saja.

2. Penyesuaian tarif, yang kadangkala membingungkan masyarakat sebagai wajib pajak dan yang tidak pernah diberitahu sebelumnya tentang penyesuaian tarif terutama bagi masyarakat dipedesaan.

3. Kurangnya kesadaran wajib pajak daerah.

4. Kemampuan dan keterampilan pegawai yang belum merata.

5. Pengolahan data yang belum tertata secara baik.

6. Pemahaman pegawai terhadap tata kerja dan prosedur belum merata.

7. Jabatan struktural sebagian belum terisi.

8. Sarana mobilitas yang belum memadai.

Usaha-usaha dalam rangka mengatasi atau paling tidak mengurangi hambatanhambatan sebagaimana tersebut diatas perlu dilakukan langkah-langkah antisipatif sebagai berikut:

1. Meningkatkan kesadaran wajib pajak dengan memberikan informasi yang seluas luasnya kepada masyarakat melalui berbagai media antara lain spanduk, dan papan himbauan serta siaran radio.

2. Mengupayakan peningkatan kompetensi SDM aparatur.

3. Melakukan pendataan baik pajak daerah serta membantu pendataan PBB.

4. Memelihara base data pajak daerah.

5. Melakukan monitoring dan pengawasan serta penagihan kepada wajib pajak baik pajak daerah serta pajak PBB.

6. Mengusulkan pengisian jabatan yang lowong sesuai struktur organisasi.

7. Memantapkan koordinasi dan konsultasi baik sesama unit kerja perangkat daerah maupun dengan pemerintah propinsi.

\section{D.Kesimpulan}

Berdasarkan uraian tersebut di atas maka dapat diambil kesimpulan yang merupakan jawaban terhadap permasalahan yang telah disusun yaitu berdasarkan hasil penelitian di lapangan bahwa masih terdapat hambatan dalam pelaksanaan perolehan Pajak Daerah antara lain: Kurangnya kesadaran wajib Pajak Daerah dalam melakukan pembayaran Pajak Daerah kurangnya Kemampuan dan keterampilan pegawai yang belum merata. Jelaslah bahwa Pajak Daerah mempunyai peranan dalam pelaksanaan Pembangunan Daerah, karena hasil penerimaan dari Pajak Daerah di Kabupaten Karo seluruhnya dipergunakan untuk membiayai penyelenggaraan daerah dan menunjang pelaksanaan Pembangunan Daerah.

Guna lebih meningkatkan penerimaan Pajak Daerah yang pada akhirmya mempunyai peranan yang sangat penting terhadap Pembangunan Daerah di Kabupaten Karo, maka berdasarkan hasil penelitian dapat diajukan beberapa saran sebagai berikut:

1. Pemerintah Daerah Kabupaten Karo Perlu meningkatkan kembali sosialisasi Peraturan Daerah mengenai Pajak Daerah melalui media massa dan elektronika dalam menjelaskan fungsi dan peran Pajak Daerah terhadap pelaksanaan Pembangunan Daerah yang intinya 
akan meningkatkan kesadaran para wajib pajak dalam melakukan pembayaran Pajak Daerah.

2. Pemerintah Daerah Kabupaten Karo perlu melakukan kebijakan pajak (Fiscal Policy) terhadap para investor dengan cara memberikan insentif rangsangan berupa pembebasan pajak (Tax Holiday) atau pengurangan pajak yang nantinya diharapkan banyak investor asing yang akan menanamkan modalnya terutama di daerah kawasan wisata yang menurut pemantauan peneliti sangat besar potensinya dalam menggali pendapatan daerah melalui pajak daerah yang setiap tahun pada hari libur dan hari-hari tertentu (seperti liburan Idul Fitri, Natal dan Tahun Baru) antusias pengunjung sangat besar tentunya hal ini akan berdampak dalam peningkatan pendapatan dalam rangka menunjang pelaksanaan pembangunan daerah.

\section{Daftar Pustaka}

Darwin. 2010. "Pajak Daerah dan Retribusi Daerah". Jakarta: Mitra Wacana Media.

Fidel. 2010."Cara Mudah dan Praktis Memahami Masalah-masalah Perpajakan".Jakarta: Murai Kencana.

Sumarsan Thomas. 2010. "Perpajakan Indonesia, Pedoman Perpajakan yang Lengkap Berdasarkan Undang-Undang Terbaru". Jakarta Barat. Indeks.

Mardiasmo. 2008. "Perpajakan, Edisi Revisi 2008". Yogyakarta: Andi.

Sutedi Andriani. 2011. "Hukun pajak". Jakarta: Sinar Grafika.

Suandy Erly. 2011. "Hukum Pajak. Edisi ke 5". Jakarta Selatan: Salemba Empat.

Saidi Muhammad Djafar. 2014. 'Pembaharuan Hukum Pajak. Edisi Terbaru". Jakarta : Rajawali Pers.

Ismawan Indra. 2001. "Memahami Reformasi Perpajakan 200". Jakarta: PT. Elex Madia Komputindo Kelompok Gramedia.

Suharsono Agus. 2015. "Ketentuan Umum Perpajakan". Yogyakarta: Graha Ilmu

Pudyatmoko, Y Sri. 2009. "Pengantar Hukum Pajak. Edisi Terbaru". Yogyakarta: Andi.

Ilyas Wirawan B. dan Richard Burton. 2004. "Hukum Pajak". Edisi Revisi". Jakata: Salemba Empat.

Siahaan Marihot Pahala. 2017. "Tax Amnesty di Indonesia". Jakarta: Rajawali Pers.

Bohari H. 2010. "Pengantar Hukum Pajak"'. Jakarta: Rajawali Pers.

Pandiangan Roristua. 2015. "Hukum Pajak". Yogyakarta: Graha Ilmu.

Pudyatmoko, Y Sri. 2008. "Pengantar Hukum Pajak. Edisi Revisi". Yogyakarta: Andi.

Siahaan, Marihot p, 2005. Pajak Daerah Dan Retribusi Daerah Edisi 1, PT. Raja Grafindo Persada, Jakarta

Simamora, Janpatar. "Development of Constitutional Interpretation by Constitutional Court of Indonesia in the Context of State Institutions' Authority Dispute Settlement." IOSR Journal Of Humanities And Social Science (IOSR-JHSS) Volume 24: 45-54. Lihat juga dalam Simamora, Janpatar. "Considering Centralization Of Judicial Review Authority In Indonesia Constitutional System." IOSR Journal Of Humanities And Social Science (IOSRJHSS) Vol 21 (2016): 26-32.

Simamora, Janpatar. "Comparison of Constitutional Court Authority Between Indonesia and South Korea." Jurnal Dinamika Hukum 15.3 (2015): 331-338.

Simamora, Janpatar. "Problematika Penyelesaian Sengketa Kewenangan Lembaga Negara Oleh Mahkamah Konstitusi." Mimbar Hukum-Fakultas Hukum Universitas Gadjah Mada 28.1 (2016): 77-92. 
Simamora, Janpatar. "Reformasi Birokrasi, Good Governance dan Etika Pelayanan Publik." Jurnal Ilmu Administrasi: Media Pengembangan Ilmu dan Praktek Administrasi 10, no. 1 (2013): 39-6o.

Nano Hanafi, Buku Saku Perpajakan Indonesia, Jakarta, 2004.

Kunarjo. 1993. Perencanaan dan Pembiayaan Pembangunan Daerah. Universitas Indonesia. Jakarta.

Tunggal, Hadi Setia. 1999, Tanya Jawab : Pajak Daerah Dan Retribusi Daerah, penerbit Harvarind, Jakarta.

Peraturan Perundang-undang

Undang-Undang Dasar Negara Republik Indonesia tahun 1945

Undang-undang Nomor 28 tahun 2007 tentang perubahan ketiga atas undang- undang nomor 6 tahun 1983 tentang ketentuan umum dan tata cara perpajakan

Undang-undang nomor 9 tahun 2015 tentang perubaha kedua atas Undang- undang Nomor 23 tahun 2014 tentang Pemerintahan Daerah

Undang-undang Nomor 28 Tahun 2009 Tentang Pajak dan Retribusi Daerah

Dalam Undang-Undang No. 28 Tahun 2009 Tentang Pajak Daerah dan Retribusi Daerah

Peraturan daerah Kabupaten Karo Nomor 03 tahun 2012 Tentang Pajak Daerah. 